\title{
COVID-19 ve Pankreas
}

\author{
COVID-19 and Pancreas
}

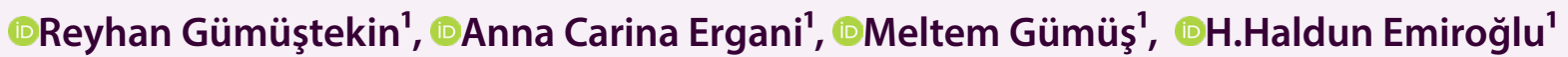

'Selcuk University School of Medicine Department of Pediatrics, Division of Pediatric Gastroenterology, Hepatology and Nutrition, Konya, Turkey

\section{ÖZ}

Coronavirüs Hastalığı-2019 (COVID-19) pandemisi, Aralık 2019'da bilinmeyen kökenli bir pnömoni salgını ile başladı. SARS-CoV-2 enfeksiyonunda öksürük, nefes darlığı ve ateş gibi klasik pnömoni semptomlarının yanı sıra; ishal, bulantı, kusma ve karın ağrısı gibi mide-bağırsak semptomları da mevcut olabilir. Bununla birlikte, son çalışmalar, pankreas dahil diğer organ tutulumlarını bildiren COVID-19 hastalarının sayısının arttığını göstermiştir. Virüslerin çocuklarda pankreatit nedeni olduğu bilinmesine rağmen, SARS-CoV-2 virüsüyle ilişkili akut pankreatit tanımlanmaya yeni başlanmış olup bu konudaki güncel veriler sınırlı ve prevalansı ve patogenezi hakkında çok az şey bilinmektedir. Bu derlemede SARS-CoV-2 enfeksiyonu sırasında pankreas tutulumu konusundaki en son literatür bilgileri incelenecektir.

Anahtar Kelimeler: COVID-19, pankreas, gastroenteroloji

\section{ABSTRACT}

The Coronavirus Disease 2019 (COVID-19) pandemic started in December 2019 with a pneumonia outbreak of unknown origin. In SARS-CoV-2 infection, in addition to classic pneumonia symptoms such as cough, shortness of breath and fever; gastrointestinal symptoms such as diarrhea, nausea, vomiting, and abdominal pain may also present. However, recent studies have shown an increasing number of COViD-19 patients reporting other organ manifestations including pancreas. Although viruses are known to be a cause of pancreatitis in children, acute pancreatitis associated with the SARS-CoV-2 virus has just begun to be defined, and current data on this subject are limited,and little is known about its prevalence. and pathogenesis. In this review, the most recent literature on pancreas involvement during SARS-CoV-2 infection will be reviewed.

Keywords.: COVID-19, pancreas, gastroenterology

\section{COVID-19 VE PANKREAS}

Coronavirüs Hastalığı-2019 (COVID-19) pandemisi, Aralık 2019'da, Çin'in Wuhan Eyaleti Hubei bölgesinde bilinmeyen kökenli bir pnömoni salgını ile başladı. COVID-19'un bugüne kadar 222 ülkeyi etkilediği, 137.866.311 kişinin enfekte olduğu, 2.965.707 kişinin hayatını kaybettiği global bir pandemiye dönüştüğü ve yaklaşık \%1-3'lük bir ölüm oranı ile halk sağlığına ciddi bir tehdit oluşturmaya devam ettiği bilinmektedir $(1,2)$.

Daha önce coronavirus 2019 olarak adlandırılan virüs, genetik yapısı MERS koronovirüsü ve SARS koronavirüsü ile benzerlik göstermesi nedeniyle SARS- CoV-2 olarak adlandırılmıştır (3). Yeni tanımlanan virüsün yüksek yayılım hızı ve bulaşma riski nedeni ile acil ve etkili önlemler geliştirebilmek için hastalığın epidemiyolojik özelliklerinin tanımlanması ve patofizyolojik mekanizmalarının aydınlatılması gerekmektedir (4-6).

SARS-CoV-2 enfeksiyonunda öksürük, nefes darlığı ve ateş gibi klasik pnömoni semptomlarına ek olarak diyare, bulantı, kusma, karın ağrısı gibi gastrointestinal semptomlar da bulunabilir (4). Literatürde karaciğer, 
pankreas, kalp, böbrek, cilt veya nörolojik tutulum ile ilişkili makaleler artan bir şekilde bildirilmektedir (2).

Akut pankreatit etiyolojisinde safra taşı, hipertrigliseridemi, hiperkalsemi, ilaçlar, travma ve viral etkenler rol alabilmektedir. Viral etkenler arasında SARSCoV-2 virüsü ile ilişkili akut pankreatit yeni tanımlanmaya başlanmış olup prevalansı ve patogenezi hakkında çok az şey bilinmektedir (7,8-11). Son çalışmalarda giderek artan bir şekilde pankreas tutulumunun görüldüğü bildirilmesine rağmen bu konuda güncel veriler sınırlıdır.

$\mathrm{Bu}$ derlemede SARS-CoV-2 enfeksiyonu sırasında pankreas tutulumu konusundaki güncel literatür bilgileri sunulmaktadır.

\section{Pankreas Hasarı Patofizyolojisi}

SARS-CoV-2 virüsünün pankreas hasarının mekanizması henüz bilinmemektedir.

Konakçı hücrelere virüsün girişi $A C E-2$ reseptörleri aracılığı ile olmaktadır. Pankreasın ekzokrin bezleri ve adacık hücrelerinde ACE-2'nin messenger RNA düzeylerinin, akciğer alveoler epitel hücrelerinden daha güçlü bir şekilde ifade edilmesi nedeniyle pankreas SARS-CoV-2 enfeksiyonu için potansiyel bir hedef olabilir. Pankreatik asiner hücrelerin iltihaplanma ve ödem ile doğrudan tahrip edilmesi ile oluşan sitopatik etki veya CoV-2 replikasyonu veya dolaylı olarak SARS-CoV-2'nin neden olduğu sistemik immun yanıt etkisiyle pankreatit veya pankreas enzim anormallikleri ortaya çıkar $(9,12,13)$. Ayrıca pankreatik enzim aktivasyonu, kompleman sistemi aktivasyonu, mikrosirkülasyon bozukluğu, lökosit aşırı aktivasyonu ve pankreas asiner hücre apoptozu ve nekrozu dahil olmak üzere çeşitli faktörler de katkıda bulunabilir (14).

Şiddetli COVID-19 enfeksiyonunda, yüksek IL-6, IL 8, IL10'un eşlik ettiği sitokin fırtınası nedeni ile pankreas hasarı daha ağırdır. Benzer şekilde, şiddetli akut pankreatit enfeksiyonunda da IL-6, IL8, IL-10 düzeylerinin yüksek olduğu sitokin fırtınası gerçekleşir (15).

Ayrıca SARS-CoV-2 virüsünün çeşitli anatomik organlarda epitelde bulunan ACE-2 reseptörlerinin endotel disfonksiyonu ve staza neden olarak iskemiye ve trombotik hastalığa eğilimi artırması, pankreatit etyolojisinde önemli olabilir (16).

Akut pankreatit, geçmişte çeşitli viral enfeksiyonların bir komplikasyonu olarak tanımlanmıştır. Yapılan çalışmalarda SARS-CoV virüsünün otopsilerde pankreatik dokuda izole edilmiş olsa da SARS-CoV enfeksiyonunun bir komplikasyonu sonucu geliştiği kesin olarak kanıtlanmış bir akut pankreatit olgusu henüz bildirilmedi (17).

\section{COVID-19 ve pankreas hasarının dünya verileri:}

Akut pankreatit sıklığı son on yılda artma eğilimindedir. Son çalışmalarda, çocuklarda akut pankreatit insidansı nın 1/10.000 olduğu gösterilmiştir (18). Peery ve ark. yaptığı çalışmada, Amerika Birleşik Devletleri'nde akut pankreatit tanısıyla her yı 250.000 başvuru olduğu ve son 10 yılda başvuruların \% 20 oranında artış gösterdiği bildirilmiştir (19).

İspanya'da 50 hastanenin acil servisinde yapılan retrospektif bir çalışmada Covid-19 enfeksiyonu geçiren 63.000'den fazla hastada akut pankreatit insidansı \%0.07 saptanmıştır (20).

Bir diğer retrospektif çalışmada ABD'de 12 hastanede yatan 11.883 Covid-19 olgusu analiz edilmiş ve 32 hastada (\%0.27) akut pankreatit saptanmıştır. Yapılan çalışmalarda COViD-19 pandemisi sırasında akut pankreatit sıklığının ve riskinin arttığı kesin olarak gösterilememiştir (21).

Akut pankreatit tanısı yetişkinlerde Atlanta kriterleri, çocuklarda Uluslararası Çocuk Pankreatitli Olguların Çalışma Grubu (INSPPIRE) kriterlerine göre konulur. Atlanta ve Uluslararası Çocuk Pankreatitli Olguların Çalışma Grubu (INSPPIRE) kriterlerine göre, akut pankreatit tanı, aşağıdaki üç belirtiden en az ikisini gerektirir.

a. pankreatiti düşündüren akut şiddetli karın ağrısı;

b. serum lipaz ve/veya amilaz düzeyi üst normal sınırın üç katından fazla;

c. radyolojik olarak akut pankreatit görüntüleme bulguları $(8,14,22,23)$. Bazı COViD-19 çalışmalarında, akut pankreatit tanısı Atlanta veya Uluslararası Çocuk Pankreatitli Olguların Çalışma Grubu (INSPPIRE) kriterlerini sağlamadan yalnızca pankreas enzimlerinde artış olarak tanımlanmıştır. Fakat pankreas enzim yüksekliği, akut pankreatit dışı nedenler (şiddetli COVID-19 enfeksiyonunun asidoz, solunum, böbrek yetmezliği ve diyabet gibi komplikasyonları ile ilişkili olabilir $(9,23)$.

Wang ve arkadaşları tarafından yapılan bir çalışmada COVID-19 pnömonisi olan 52 hastanın, \%17'si amilaz veya lipaz değerlerinde anormallik saptandığı, ancak şiddetli pankreatitin klinik semptomlarının gelişmemiş olduğu bildirilmiştir. Pankreas hasarı olarak sınıflandırılan hastaların ishal insidansı ve kreatinin düzeyleri daha yüksek idi ve bu nedenle COViD-19 pnömonisi olan hastalardaki amilaz ve lipazın yüksekliğinin, bağırsak inflamasyonu ve azalmış böbrek atılımından kaynaklanabileceği görüşünü desteklemektedir (9).

Liu ve ark. COVID-19 pnömonisi olan 67 hastanın \%17'sinde pankreas hasarı görüldüğünü bildirdi. Bununla birlikte, bilgisayarlı tomografide (BT) pankreas hasarı vakaların \%7,46'sında saptandı. Hastalarda karın ağrısı yok idi (11).

Jin ve arkadaşları tarafından bildirilen çalışmada, COViD-19 hastalarının \% 48'inde lipaz yüksekliği 
bildirilmiştir. Lipaz değeri normalin 3 katı olan hastaların hiçbirinin Atlanta kriterlerini karşılamadığı ve hiperlipazemi görülmesine rağmen akut pankreatitin daha az saptandığı bildirilmiştir (13).

Alloway, karın ağrısı ile başvuran ve lipaz yüksekliği eşlik eden 7 yaşında olgu bildirmiştir. Başlangıçta solunum semptomları olmayan hastanın BT'sinde nekrotizan pankreatit bulguları kanıtlanmıştır ve takibinde Covid-19 pozitif olduğu saptanmıştır (24). Steven ve ark. 10 yaşında akut pankreatit ile başvuran ve takibinde COViD-19 enfeksiyonuna sekonder multisistem enflamatuvar sendrom gelişen bir olgu bildirmiştir (25).

Bazı hastalarda enfeksiyonun başlangıcında COVID-19 semptomları ve karın ağrısı ortaya çıkabilir. Bazı hastalarda da COVID-19 tanısı aldıktan günler sonra akut pankreatit gelişebilir (26).

Anand ve ark. taburculuktan beş gün sonra klinik ve görüntüleme bulgularına göre akut pankreatit tanısı konulan COVID 19 pnömoni vakası bildirmişlerdir (27).

Hadi ve ark. ARDS ve böbrek yetmezliği ile seyreden iki adet şiddetli akut pankreatit olgusu bildirmiştir. Beş kişilik ailenin ikisinde pankreatit enfeksiyonu saptanmış olup, ailenin üçüncü bireyi yoğun bakımda multiorgan yetmezliği tablosunda izlenmiş olup, pankreatit kliniği gelişmemiştir. Diğer iki aile bireyi SARS-COV-2 pozitif olup, hafif semptomlarla atlatmış ve hastaneye yatış gerektirmemiştir. Beş kişilik aileden neden sadece iki kişinin pankreatit geçirdiği anlaşılamamıştır (Tablo 1) (14).
Akut pankreatit başvurularının büyük çoğunluğunda hastalık (\% 80) hafif, kendi kendini sınırlayıcıdır; ancak uzun vadede, endokrin disfonksiyon ve özellikle bozulmuş glukoz metabolizması veya diyabet geliştiği bildirilmiştir (19).

Yang ve ark. 2006'da SARS hastalarında virüsün ACE2 yoluyla pankreas adacıklarına zarar vermesi nedeniyle gelişen hipergliseminin mortalite ve morbidite için bağımsız bir belirleyici faktör olduğu hipotezini ileri sürmüştür. Çalışmada hiperglisemi, mortalitenin bağımsız bir belirleyicisiydi ve hafif SARS hastalarında bile benzer şekilde idi ve açlık glikoz düzeyi yüksek idi. Takipte kortikosteroid almayan 39 hastanın 20'sinde hastanede yatış sırasında diabet gelişti. Ancak 3 yıllık takipten sonra, bu hastalardan sadece ikisinde diabetes mellitus kalıcı idi. Ayrıca 3 yıl takipten sonra, SARS grubunda ve sağlıklı SARS geçirmeyen kardeşlerde açlık, tokluk kan glikoz düzeyleri ve insülin düzeyleri benzer idi. Bu çalışma, SARS enfeksiyonun pankreatik hücrelere etkisinin geçici olduğunu göstermektedir. Açlık kan glikoz düzeyinin yüksekliği, pankreas hasarının göstergesi ve mortalite için risk faktörü olabileceği bildirilmiştir. Ancak, bu hipotezi test etmek için deneysel çalışmalara ihtiyaç vardır (28). Ayrıca virüsün, $\mathrm{Na}+/ \mathrm{H}+$ transport pompası ile ve laktat yolakları aracılığıyla ACE2 bloke edildiğinde, glikoz regülasyonunu etkilemesi, endotel hasarına ve insülin direncine yol açan hücresel ve reaktif hipoksiye yol açabilir. Buna ek olarak, ekzokrin pankreasın enfeksiyonu enflamatuvar sitokinler yoluyla

\begin{tabular}{|c|c|c|c|c|c|c|c|c|}
\hline Çalışma & $\begin{array}{l}\text { Çalışmanın } \\
\text { özelliği }\end{array}$ & $\begin{array}{l}\text { Pankreas hasarı } \\
\text { gelişen hasta sayısı/ } \\
\text { toplam hasta sayısı }\end{array}$ & $\begin{array}{l}\text { Artmış } \\
\text { amilaz }\end{array}$ & Artmış lipaz & $\begin{array}{l}\text { Karın } \\
\text { ağrısı }\end{array}$ & $\begin{array}{l}\text { Görüntüleme } \\
\text { bulguları }\end{array}$ & $\begin{array}{l}\text { Şiddetli } \\
\text { hastalık }\end{array}$ & \\
\hline Liu ve ark. & $\begin{array}{l}\text { Pankreas } \\
\text { hasarını } \\
\text { gösteren } \\
\text { çalışmalar }\end{array}$ & 13/121 (\%10.7) & $\begin{array}{l}13 / 121 \\
(\% 10.7)\end{array}$ & 12/121(\%9.9) & $3 / 13$ & $\begin{array}{l}\text { Normal:8 (\%3.6) } \\
\text { Genişleme:5 (\%4.1) }\end{array}$ & $12 / 67$ & $\begin{array}{l}\text { Şiddetli olmayan vaka } \\
\% 1.8 \\
\text { Şiddetli (\%17.9) } \\
\text { NSAili:2 } \\
\text { Kortikosteroid:4 }\end{array}$ \\
\hline $\begin{array}{l}\text { McNabbar } \\
\text { ve ark. }\end{array}$ & $\begin{array}{l}\text { Pankreas } \\
\text { hasarını } \\
\text { gösteren } \\
\text { çalışmalar }\end{array}$ & 9/71 (\%12.1) & Yok & $\begin{array}{l}\text { 9/71 (12.1\%); } \\
2 / 71(2.8 \%) \\
\text { >üst sınırın } \\
3 \text { katı }\end{array}$ & Yok & $\begin{array}{l}\text { Pankreatit bulgusu } \\
\text { yok }\end{array}$ & $\begin{array}{l}4 / 9 \\
(\% 44.4)\end{array}$ & Klinik yok \\
\hline $\begin{array}{l}\text { Wang ve } \\
\text { ark. }\end{array}$ & $\begin{array}{l}\text { Pankreas } \\
\text { hasarını } \\
\text { gösteren } \\
\text { çalışmalar }\end{array}$ & 9/52 (\%17.3) & $\begin{array}{l}7 / 52 \\
(\% 13.5)\end{array}$ & $5 / 52(\% 9.6)$ & Yok & $\begin{array}{l}\text { Pankreatit bulgusu } \\
\text { yok }\end{array}$ & $\begin{array}{l}4 / 9 \\
(\% 44.4)\end{array}$ & $\begin{array}{l}\text { 7/9 hasta KS } \\
\text { Klinik yok }\end{array}$ \\
\hline $\begin{array}{l}\text { Hadi ve } \\
\text { ark. }\end{array}$ & $\begin{array}{l}\text { Olgu } \\
\text { sunumu }\end{array}$ & & Var & Var & $1 / 3$ & $\begin{array}{l}1 \text { hastada } A \text {. } \\
\text { Pankreatit bulgusu }\end{array}$ & & $\begin{array}{l}3 \text { hastanın } 2 \text { sinde a. } \\
\text { Pankreatit kliniği var. }\end{array}$ \\
\hline $\begin{array}{l}\text { Aloysius } \\
\text { ve ark. }\end{array}$ & $\begin{array}{l}\text { Olgu } \\
\text { sunumu }\end{array}$ & & Var & Var & Var & normal & & $\begin{array}{l}\text { Klinik a.pankreatit ile } \\
\text { uyumlu }\end{array}$ \\
\hline $\begin{array}{l}\text { Alloway ve } \\
\text { ark. }\end{array}$ & $\begin{array}{l}\text { Olgu } \\
\text { sunumu }\end{array}$ & & Var & Var & Var & Nekrotizan AP & & $\begin{array}{l}\text { Solunum bulgularının } \\
\text { eşlik etmediği, } 7 \\
\text { yaşında a.pankreatit } \\
\text { olgusu }\end{array}$ \\
\hline $\begin{array}{l}\text { Anand ve } \\
\text { ark. }\end{array}$ & $\begin{array}{l}\text { Olgu } \\
\text { sunumu }\end{array}$ & & Yok & Yok & Var & $\begin{array}{l}\text { Ödematöz } \\
\text { pankreatit }\end{array}$ & & A.Pankreatit kliniği var. \\
\hline $\begin{array}{l}\text { Steven ve } \\
\text { ark. }\end{array}$ & $\begin{array}{l}\text { Olgu } \\
\text { sunumu }\end{array}$ & & Var & Var & Var & $\begin{array}{l}\text { A. Pankreatit ile } \\
\text { uyumlu }\end{array}$ & & $\begin{array}{l}10 \text { yaşındaki akut } \\
\text { pankreatit olgusunda } \\
\text { MIS-C gelişmiş. }\end{array}$ \\
\hline
\end{tabular}


beta hücrelerinde hasara yol açabilir $(29,30)$. Ayrıca, SARSCoV - 2'nin ACE 2'ye reseptör afinitesi SARS-CoV ile karşılaştırıldığında daha fazladır (28).

Benzer şekilde SARS-CoV-2 enfeksiyonu da teorik olarak akut diyabete yol açan adacık hasarına neden olabilir. Wang ve arkadaşları tarafından yapılan çalışmada pankreas hasarı olan dokuz hastadan altısında hiperglisemi saptandı (10) .

SARS-COV-2 virüsünün, pankreas fonksiyonlarına etkisi bilinmemektedir. SARSCoV - 2 ve akut pankreatit arasında ilişki kanıta dayalı değil, mevcut verilerin yorumlanması zor ve akut pankreatit sık görülmesine rağmen COVID-19 hastalarında nadir görülmektedir. Hastalığın gerçek sıklığını ve klinik önemini belirlemek için daha ileri araştırmalar gerekmektedir.

\section{SONUÇ}

Pandemi sürecinde akut pankreatit vakalarında SARSCOV-2 araştırılmalı ve SARS-COV-2 enfeksiyonu olan hastalarda karın ağrısı semptomu geliştiğinde amilaz ve lipaz düzeyleri bakılmalıdır. SARS-CoV-2'yi akut pankreatitin yeni bir etiyolojisi olarak düşünmek önemlidir ve idiyopatik pankreatit vakaları, idiyopatik pankreasın COVID-19 ile ilişkisi göz önüne alındığında SARS-CoV-2 enfeksiyonu için daha fazla test yapılmasını gerektirir.

\section{ETIK BEYANLAR}

Hakem Değerlendirme Süreci: Harici çift kör hakem değerlendirmesi.

Çıkar Çatışması Durumu: Yazarlar bu çalışmada herhangi bir çıkara dayalı ilişki olmadığını beyan etmişlerdir.

Finansal Destek: Yazarlar bu çalışmada finansal destek almadıklarını beyan etmişlerdir.

Yazar Katkıları: Yazarların tümü; makalenin tasarımına, yürütülmesine, analizine katıldığını ve son sürümünü onayladıklarını beyan etmişlerdir.

\section{KAYNAKLAR}

1. World Health Organization. Rolling updates on coronavirus disease (COVID-19); 2020. WHO Coronavirus (COVID-19) Dashboard |WHO Coronavirus (COVID-19) Dashboard With Vaccination Data [accessed 16.04.2021].

2. Asselah T, Durantel D, Pasmant E, Lau G, Schinazi RF. COVID-19: Discovery, diagnostics and drug development. J Hepatol. 2021;74(1):168-84

3. Bahrami A, Ferns GA. Genetic and pathogenic characterization of SARS-CoV-2: a review. Future Virol. 2020;10.2217/fvl-2020-0129.

4. Pascarella G, Strumia A, Piliego C, et al. COVID-19 diagnosis and management: a comprehensive review. J Intern Med. 2020;288(2):192-206.

5. Agarwal N, Pitchumoni CS, Sivaprasad AV. Evaluating tests for acute pancreatitis. Am J Gastroenterol. 1990;85(4):356-66.

6. Li H, Liu SM, Yu XH, Tang SL, Tang CK. Coronavirus disease 2019 (COVID-19): current status and future perspectives. Int J Antimicrob Agents. 2020;55(5):105951.
7. Cheung S, Delgado Fuentes A, Fetterman AD. Recurrent Acute Pancreatitis in a Patient with COVID-19 Infection. Am J Case Rep. 2020;21:e927076.

8. Aloysius MM, Thatti A, Gupta A, Sharma N, Bansal P, Goyal H. COVID-19 presenting as acute pancreatitis. Pancreatology. 2020;20(5):1026-7.

9. Kandasamy S. An unusual presentation of COVID-19: Acute pancreatitis. Ann Hepatobiliary Pancreat Surg. 2020;24(4):539-41.

10. Wang $F$, Wang $\mathrm{H}$, Fan J, Zhang $\mathrm{Y}$, Wang $\mathrm{H}$, Zhao Q. Pancreatic Injury Patterns in Patients With Coronavirus Disease 19 Pneumonia. Gastroenterology. 2020;159(1):367-70.

11. Liu F, Long X, Zhang B, Zhang W, Chen X, Zhang Z. ACE2 Expression in Pancreas May Cause Pancreatic Damage After SARS-CoV-2 Infection. Clin Gastroenterol Hepatol. 2020;18(9):2128-30.

12. Patel KP, Patel $P A$, Vunnam RR, Hewlett $A T$, Jain $R$, Jing $R$, Vunnam SR. Gastrointestinal, hepatobiliary, and pancreatic manifestations of COVID-19. J Clin Virol. 2020;128:104386.

13. Jin DX, Yang AL, Suleiman SL, et al. Marked serum lipase elevations are associated with longer hospitalizations in patients with nonpancreatic hyperlipasemia. Gastroenterology 2019;156:1033-4.

14. Hadi A, Werge M, Kristiansen KT, et al. Coronavirus Disease-19 (COVID-19) associated with severe acute pancreatitis: case report on three family members. Pancreatology. 2020;20:665-7.

15. Hegyi P, Szakács Z, Sahin-Tóth M. Lipotoxicity and Cytokine Storm in Severe Acute Pancreatitis and COVID-19. Gastroenterology. 2020;159(3):824-7.

16. Bikdeli B, Madhavan MV, Jimenez D, et al. COVID-19 and Thrombotic or Thromboembolic Disease: Implications for Prevention, Antithrombotic Therapy, and Follow-Up: JACC Stateof-the-Art Review. J Am Coll Cardiol. 2020;75(23):2950-73.

17. He L, Ding YQ, Che $X Y$, et al. [Expression of the monoclonal antibody against nucleocapsid antigen of SARS-associated coronavirus in autopsy tissues from SARS patients]. Di Yi Jun Yi Da Xue Xue Bao. 2003;23(11):1128-30.

18. Pohl JF, Uc A. Paediatric pancreatitis. Curr Opin Gastroenterol. 2015;31(5):380-6.

19. Peery AF, Crockett SD, Barritt AS, et al. Burden of gastrointestinal, liver, and pancreatic diseases in the United States. Gastroenterology 2015;149:1731-41.

20. Miró Ò, Llorens $P$, Jiménez $S$, et al. Frequency of five unusual presentations in patients with COVID-19: results of the UMC19-S1. Epidemiol Infect. 2020;148:e189.

21. Inamdar S, Benias PC, Liu Y, et al. Prevalence, Risk Factors, and Outcomes of Hospitalized Patients With Coronavirus Disease 2019 Presenting as Acute Pancreatitis. Gastroenterology. 2020;159(6):2226-8.e2.

22. Abu-El-Haija M, Lin TK, Nathan JD. Management of acute pancreatitis in children. Curr Opin Pediatr. 2017;29(5):592-7.

23. Meireles PA, Bessa F, Gaspar P, et al. Acalculous acute pancreatitis in a COVID-19 patient. Eur J Case Rep Intern Med. 2020;7:1710.

24. Alloway BC, Yaeger SK, Mazzaccaro RJ, Villalobos T, Hardy SG. Suspected case of COVID-19-associated pancreatitis in a child. Radiol Case Rep. 2020;15(8):1309-12.

25. Stevens JP, Brownell JN, Freeman AJ, Bashaw H. COVID-19associated Multisystem Inflammatory Syndrome in Children Presenting as Acute Pancreatitis. J Pediatr Gastroenterol Nutr. 2020;71(5):669-71.

26. de-Madaria E, Capurso G. COVID-19 and acute pancreatitis: examining the causality. Nat Rev Gastroenterol Hepatol. 2021;18(1):3-4

27. Anand ER, Major C, Pickering O, Nelson M. Acute pancreatitis in a COVID-19 patient. Br J Surg. 2020;107:e182.

28. Yang JK, Feng Y, Yuan MY, et al. Plasma glucose levels and diabetes are independent predictors for mortality and morbidity in patients with SARS. Diabet Med. 2006;23(6):623-8.

29. Cure E, Cumhur Cure M. COVID-19 may affect the endocrine pancreas by activating $\mathrm{Na}+\mathrm{H}+$ exchanger 2 and increasing lactate levels. J Endocrinol Invest. 2020;43(8):1167-8.

30. Jaeckel E, Manns M, Von Herrath M. Viruses and diabetes. Ann NY Acad Sci 2002;958:7e25 